\title{
The effect of conditions and storage time on course of moisture and temperature of maize grains
}

\author{
Marek Angelovič ${ }^{1}$, Koloman Krištof ${ }^{1}$, Ján Jobbágy ${ }^{1}$, Pavol Findura ${ }^{1}$, and Milan Križan ${ }^{1}$ \\ ${ }^{1}$ Faculty of Engineering, Slovak University of Agriculture, 94976 Nitra, Tr. A. Hlinku 2, Slovakia
}

\begin{abstract}
Characteristics of stored cereals significantly affect the technical solution of individual storage facilities, as well as the technical appliances used to provide storage technologies, i.e. storing aeration and off-loading. The objective of the study was to monitor the influence of atmospheric temperature and extraneous moisture on the course of temperature and moisture of maize grain during the storage. An average value of maize grain moisture was $13.6 \%$ and an average value of temperature inside of the silo was $12.3^{\circ} \mathrm{C}$ within a defined timeframe. An average moisture value of maize grain stored in the floored warehouse was $13.7 \%$, but an average temperature inside the warehouse was $21.9^{\circ} \mathrm{C}$, however extraneous conditions during the storage were unchanged. Average value of extraneous moisture was $86.5 \%$ and an average value of atmospheric temperature was $9.17^{\circ} \mathrm{C}$. It was not recorded any occurrence of animal pests in stored maize grain during the storage. Grain water content differs with the change of air moisture and temperature. Reduction of grain water content is most frequently realized by residual drying (moisture is less than $15 \%$ ); the storage stability is provided at the moisture of $12 \%$.
\end{abstract}

\section{Introduction}

Maize is an important crop which is the essential for stock rising as energy food. Drying is vital for maize safe storage. However, the unsuitable drying could decrease its feeding and processing quality $[1,2]$.

Field grain harvesting is followed by post-harvest treatment, which is essential for storage. During the postharvest treatment, grain is cleaned from substantial part of impurities and grain is dried to the moisture of 14 to $14.5 \%$ of its weight, if necessary. The purpose of the storage is to preserve and improve the grain quality. Technological properties can be improved by proper storage. Warehouses should be steady enough to protect grain against weight reduction, caused by atmospheric conditions and animal pests. We cannot avoid grain weight reduction during the storage, which is caused by respiration, diffusion and mechanical damage [3-4].

Moreover, [5] found out that previous storage history (moisture content and duration) affected subsequent storability. Storage for longer periods, given the same moisture content, resulted in lower subsequent storability, and storage at higher moisture content, given the same time period, also resulted in lower subsequent storability [5].

Even [6] stated that corn seed (Zea mays L.) very often is harvested on the ear at high moisture so as to reduce the risk of frost, insect, and disease damage. The harvest is started at seed moisture as high as $40 \%$, and ears are subsequently dried mechanically with heated air before shelling. The drying process has been a frequent cause of seed injury and great economic loss. Damage is most frequently encountered when the drying temperature is elevated or the loss of moisture is delayed. Dehumidification has long been used to safely dry perishable products and to maintain their quality during storage. Utilizing a dehumidification system which was based on heat pump technology allowed acceleration of the drying process without elevating the temperature. The heat pump system is also less expensive to operate than traditional natural gas fired systems and produces high quality seed [6].

Subsequently, [7] concluded that ear maize up to 30$33 \%$ seed moisture content can be successfully quicker dried at $50^{\circ} \mathrm{C}$. Selecting a combination of high and low temperature degrees can reduce the drying time as compared with a low temperature drying. The best combination maintains standard germination above $90 \%$ soon after artificial drying was at $50^{\circ} \mathrm{C}$ for $20 \mathrm{~h}$ before completed drying at $38^{\circ} \mathrm{C}$ for $12 \mathrm{~h}$. But after 6 months storage, the best one was $50^{\circ} \mathrm{C}$ for $16 \mathrm{~h}$ before completed drying at $38^{\circ} \mathrm{C}$ for $17.30 \mathrm{~h}$ which maintains standard germination above $88 \%$. These combinations result in saving of about 21 and $16.25 \%$ drying time, respectively with maintaining adequate levels of seed and seedling vigor [7].

Furthermore, [8] suggest that drying maize on their stem was the traditional technique frequently used; this technique must be improved to avoid contaminations and to increase the quality of drying. However, the method of storage is accountable for the most significant losses after harvest, because mildew develops when the conditions of storage (too high temperature and moisture of the air) do not tally with the final content of the dried

*Corresponding author: pavol.findura@uniag.sk 
product. Sorption isotherms of products are most important to model moisture uptake during storage and distribution. The monolayer moisture content was found to decrease with increasing temperature. These results can be used to predict the potential changes in the stability of maize grains and later for the development of a system of suitable drying [8].

Moreover, [9] found out that there were no significant changes in the content of individual carotenoids within genotypes during kernel development from 45 days after pollination through the time of harvest. Carotenoid losses through traditional grain drying were also minimal $(<9 \%)$. However, the stability of carotenoids in maize kernels over storage time after harvest was found to be dependent on both temperature and humidity. Therefore, these results support the notion that effective control of moisture content and temperature of the kernels during storage conditions is essential to reduce the speed of degradative reactions [9].

Temperature and moisture are basic indicators affecting the realization of successful long-term cereals storage. The temperature of the stored grain is an important parameter, which is influenced by the oxygen availability. Grain storage in closed areas causes a formation of carbon dioxide and oxygen reduction, because of permanent respiration. Therefore, respiration intensity of grain is reduced gradually. Aeration should provide air supply with low air moisture; even the air temperature should be at least by $5^{\circ} \mathrm{C}$ lower compared to the temperature of ventilated grain. Hygroscopicity, an ability to absorb and to exclude water vapor, has a significant impact on the grain quality and the storage ability. Grain water content differs with the change of air moisture and temperature. Reduction of grain water content is most frequently realized by residual drying (moisture is less than 15\%); the storage stability is provided at the moisture of $12 \%[2,4,10,11]$.

In addition, [12] suggested the need to determine sorption isotherms for tropical hybrid maize genotypes in relationship with seed morphology. Meanwhile, generalized prediction of seed moisture during drying or dry-storage of these varieties in tropical seed stores can be done using the Henderson-Thompson and ChungPfost models [12].

Furthermore, [13] suggested that alternative grain storage systems have been adopted when traditional bin storage capacity is exceeded or unavailable. One method is grain bag (silo bag) storage systems. This system has been used for silage or high-moisture grain storage. It was concluded that researchers, producers, and grain managers could use a similar system to monitor grains stored using this alternative storage system and to make effective management decisions [13].

\section{Materials and methods}

\subsection{Characteristics of grain warehouse}

Currently, most frequently used grain warehouses are steel silos (Fig. 1). They are high buildings with shaft chambers, which are called silo cells, with circular or hexagonal shape of floor projection. They are use to store only dry grain with the moisture content up to $14 \%$. Silo cells are made of ferroconcrete or metal. These height containers have different air distributions used for ventilation and aeration of stored grain in relation to the type and structure [2, 4].

Hangar-type warehouse are generally used for grain storage at post-harvest lines, for seed storage, as well as for temporal storage of damaged stock (Fig. 2). They are formed by a closed external roofed building structure. These buildings have quite complicated built-in ventilation system, which enables complete drying and aeration of stored grain [2, 14-15].

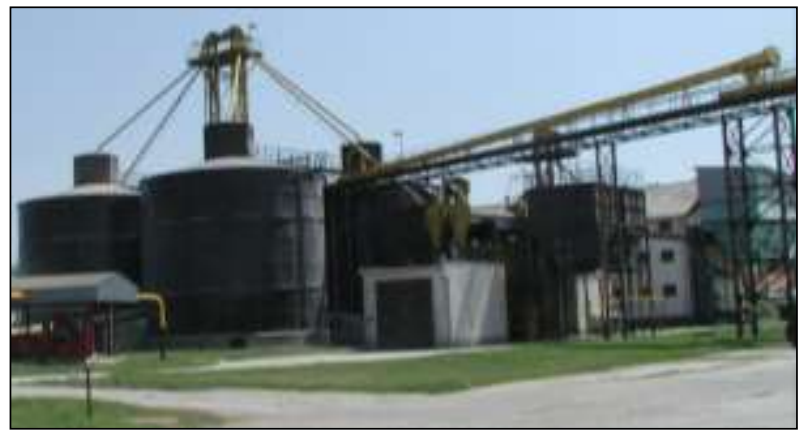

Fig. 1. Steel silos.

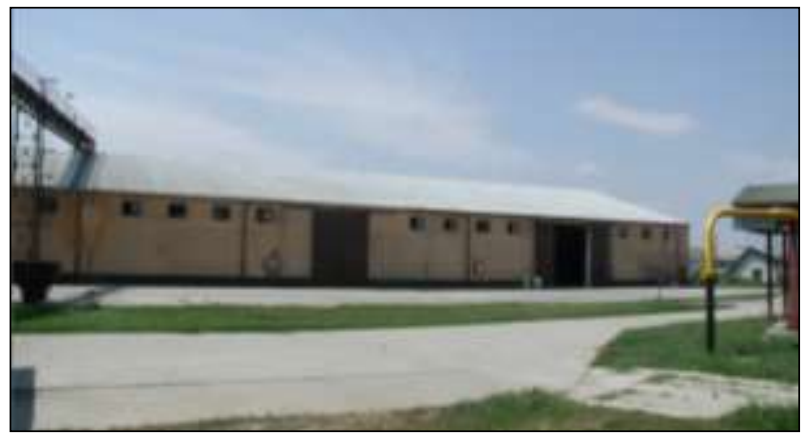

Fig. 2. Floored warehouse.

\subsection{Monitoring of the effect of storage conditions on product quality}

Characteristics of stored cereals significantly affect the technical solution of individual storage facilities, as well as the technical appliances used to provide storage technologies, i.e. storing, aeration and off-loading.

While, [1] concluded that Pasting properties of maize dried in hot air showed a decrease of peak when maize drying temperatures increased $\left(\geq 60^{\circ} \mathrm{C}\right)$, while final viscosity rose significantly. The construction of maize was also modified after hot air treatment. All these changes result in the moisture content of maize died at $105^{\circ} \mathrm{C}$ added by conditioning was just $2 \%$. When the conditioning temperature was above $75^{\circ} \mathrm{C}$, bulk density was increased significantly with the increasing temperature, but the moisture content added by conditioning and the final moisture content of the product were not changed. When the conditioning temperature below $75^{\circ} \mathrm{C}$, the quantity of feedstock significantly decreased, indicating the relative amount of 
steam was small, a bulk density decreased significantly, the state was like dry extruded [1].

The storage temperature is one of the main factors that affect the quality of storage, and considering the fact that limited studies have been conducted with maize. [16] conducted a study aimed to evaluate the quality of maize grains stored at $5,15,25$ and $35^{\circ} \mathrm{C}$ for 12 months. The results of water content, thousand grain weight, germination, electrical conductivity, and fatty acid profile indicated that major changes were observed in grain storage at higher temperatures, especially at 25 and $35^{\circ} \mathrm{C}$. Therefore, it was concluded that the safe time for storage of grains under these conditions is less compared to storage at lower temperatures [16].

Complicated chemical processes occur during cereal storage. These can ultimately cause the loss of nutritional value. Part of the loss is caused by a natural reaction (breathing kernels); another part of the loss is caused by chemical reactions that are a result of the violence of technological discipline at post-harvest treatment and storage of cereals $[2,4,17]$.

Main characteristics of the grain in relation to grain storage are:

- grain volume weight and void fraction,

- pourability of cereals,

- temperature of cereals,

- balanced water content of cereals,

- unfavourable impurities content.

We monitored:

- $\quad$ the effect of crop temperature at the beginning of storage on ventilation frequency,

- the effect of grain moisture on storage period,

- occurring of animal pests in relation on the ambient temperature and the storage period.

\subsection{Machines, devices and instruments}

We used machines, devices and equipment on the agricultural farm AgroDivízia, Ltd. in Selice for our experimental measurements. We used specialized devices and instruments belonging to the laboratory equipment for agro-physical characteristics detection, i.e. hygrometer, thermometers, digital scales, measuring device for volume weight etc.

\subsection{Experiment evaluation methods}

We used verified statistical calculation procedures for measured values evaluation. We used Microsoft Excel software for graphical processing and mathematicalstatistical results evaluation.

\section{Results and discussion}

Technology and methods of storage affect the temperature and moisture of the material, which could have an impact on the storage period and ton animal pests evolution.

We realized our experimental measurements of maize grain storage at steel silos and floored warehouses considering equipment opportunities of farm AgroDivízia, Ltd. in Selice.

\subsection{Monitoring of parameters of moisture and temperature of maize grain stored in steel silos}

Measured values of temperature and moisture of maize grain stored in monitored steel silo are represented graphically in Figure 3.

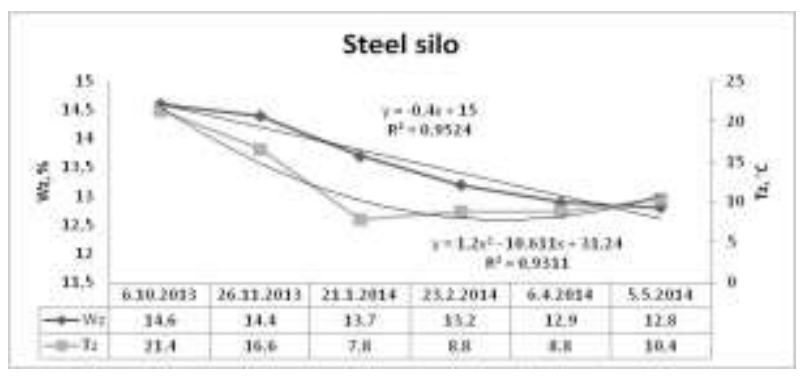

Fig. 3. Progress of moisture and temperature of maize grain stored in steel silo in dependance on storage period: $\mathrm{W}_{\mathrm{Z}}$ moisture of maize grain , $\mathrm{T}_{\mathrm{z}}$ - temperature of maize grain.

From the measured values we can state, that an average value of maize grain moisture is $13.6 \%$ within the timeframe, with the maximum value of $14.6 \%$ and minimal value of $12.8 \%$. We can state, that that an average value of temperature inside of the silo is $12.3^{\circ} \mathrm{C}$ within the timeframe, with the maximum value of $21.4^{\circ} \mathrm{C}$ and minimal value of $7.8^{\circ} \mathrm{C}$. The moisture of stored grain correlates positively with storage temperature of the grain.

Simultaneously, with the measurement realized inside of the steel silo, we monitored external conditions during the storage, i.e. air moisture and temperature, which have a significant impact on storage conditions.

Moreover, [18] stated that grains stored at $35^{\circ} \mathrm{C}$ during the 12 months period showed the greatest decrease in grain yellowness, $\mathrm{pH}$, protein solubility and breakdown viscosity. An increase in disulfide bonds within the protein structure and interaction between starch and non-starch components seems to be responsible for the changes in protein solubility and pasting properties determined in maize during the storage period. Fat acidity and the percentage of grains infected by visible molds were concluded to be very dependent of moisture content. The result of this study demonstrated that the minimum temperature of $5^{\circ} \mathrm{C}$ was able to maintain the quality of maize stored for up 12 months [18].

Measured values of atmospheric temperature and extraneous moisture in the area of monitored steel silo are represented graphically in Figure 4. 


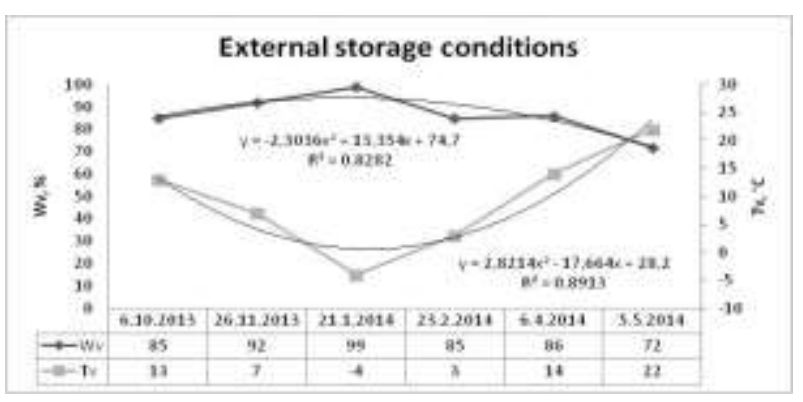

Fig. 4. Progress of air moisture and temperature during the storage in the area of monitored steel silo in dependance on storage period: $\mathrm{W}_{\mathrm{v}}$ - air moisture, $\mathrm{T}_{\mathrm{v}}-$ air temperature.

From the measured values we can state, that an average value of air moisture is $86.5 \%$, within the timeframe, with the maximum value of $99 \%$, and minimal value of $72 \%$. We can state, that that an average value of air temperature in the area of silo was $9.17^{\circ} \mathrm{C}$ within the timeframe, with the maximum value of $22^{\circ} \mathrm{C}$ and minimal value of $-4^{\circ} \mathrm{C}$. Similarly, air moisture correlates with air temperature. A reduction of atmospheric temperature is increasing extraneous moisture, resulting in a direct impact on the course of moisture and temperature of stored maize grain in steel silo (Figure 3).

[19] conducted a study to determine influence of the changes in relative humidity and temperature in storage facilities on the moisture in grain of stored soybean and maize. Grains were stored during 34 days at the temperatures of $0^{\circ} \mathrm{C}$ and $20^{\circ} \mathrm{C}$, and relative humidity of $55 \%, 73 \%, 80 \%$ and $98 \%$. It was observed that at the temperature of $0^{\circ} \mathrm{C}$ and relative humidity of $55 \%$ and $73 \%$, moisture in soybean grain decreased, $2.4 \%$ and $1.9 \%$, while at the relative humidity of $80 \%$ and $98 \%$ it increased, $0.2 \%$ and $0.6 \%$ after 34 days storage. At the temperature of $20^{\circ} \mathrm{C}$ and relative humidity of $55 \%$ and $73 \%$, moisture in soybean grain decreased $4.0 \%$ and $0.7 \%$, while at the relative humidity of $80 \%$ and $98 \%$ it increased $0.8 \%$ and $2.3 \%$, as following. During 34 days storage at $0{ }^{\circ} \mathrm{C}$ and relative humidity of $55 \%$, moisture in maize grain decreased $0.2 \%$, while at the relative humidity of $73 \%, 80 \%$ and $98 \%$ it increased $0.4 \%, 1 \%$ and $1.5 \%$. At the temperature of $20^{\circ} \mathrm{C}$ and relative humidity of $55 \%$, moisture in maize grain decreased $1.5 \%$ and at the relative humidity of $73 \%, 80 \%$ and $98 \%$ increased, $0.2 \%, 0.9 \%$ and $1.7 \%$ [19].

\subsection{Monitoring of parameters of moisture and temperature of maize grain stored in floored warehouse}

Even [20] conducted a study where moisture content (m.c.) and temperature were measured in two $1300 \mathrm{t}$ semi-underground hermetic concrete silos filled with maize which was stored for nearly three years in an upland equatorial climate. Gradual cooling of the maize took place in the first year of storage and the temperature remained constant thereafter. This could be explained by calculations of the effects of heat loss by conduction and air convection and heat gain through grain respiration. Considerable m.c. increases occurred at the maize top surface and calculations indicate that this was mainly due to air convection currents at night when the silo structure above ground was cool compared with the grain interior [20].

Measured values of temperature and moisture of maize grain stored in monitored floored warehouse are represented graphically in Figure 5.

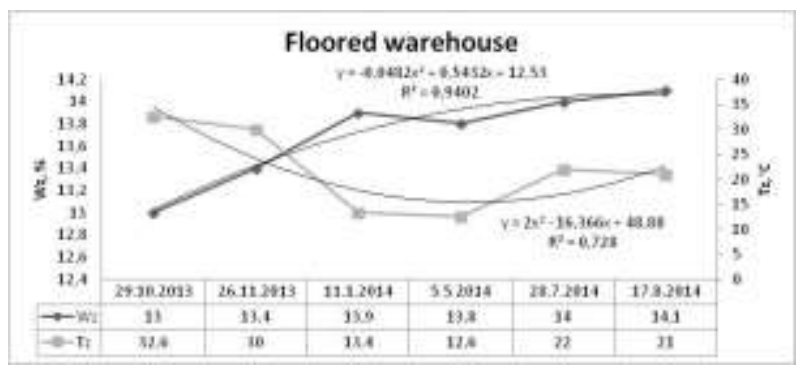

Fig. 5. Progress of moisture and temperature of maize grain stored in floored warehouse in dependance on storage period $: \mathrm{W}_{\mathrm{z}}$ - moisture of maize grain, $\mathrm{T}_{\mathrm{z}}$ - temperature of maize grain.

From the measured values, we can state that, that an average value of maize grain moisture is $13.7 \%$ within the timeframe, with the maximum value of $14.1 \%$ and minimal value of $13 \%$. We can state, that that an average value of temperature inside of the floored warehouse is $21.9^{\circ} \mathrm{C}$ within the timeframe, with the maximum value of $32.6^{\circ} \mathrm{C}$ and minimal value of $12.6^{\circ} \mathrm{C}$. The moisture of stored grain correlates with storage temperature of the grain, but with different course than in the steel silo.

As an alternative, [21] used a simulation model to quantify the effect of the AERO controller on dry matter loss, moisture content, grain temperature and required aeration time. Decision making of the AERO controller is based on simulation of the aeration process and on real time data acquisition. It proved to be an effective strategy and showed its significant potential as a nonchemical preventative practice for safe storage [21].

Moreover, nutritional changes in maize grains stored at 10,25 and $45^{\circ} \mathrm{C}$ for 6 months were studied by [22]. Significant decrease in $\mathrm{pH}$ and increase in titratable acidity was observed during storage of maize grains at 25 and $45^{\circ} \mathrm{C}$. Moisture contents of maize grains decreased by $25 \%$ at $25^{\circ} \mathrm{C}$ and $38 \%$ at $45^{\circ} \mathrm{C}$ after six months of storage. Total soluble sugars increased by $10.7 \%$ at $10^{\circ} \mathrm{C}$ and $17.3 \%$ at $25^{\circ} \mathrm{C}$, whereas a $39.5 \%$ decrease was observed after 6 months storage at $45^{\circ} \mathrm{C}$. Total available lysine and thiamine contents in maize grains decreased by 13 and $9.26 \%$ at $25^{\circ} \mathrm{C}, 16$ and $20.4 \%$ at $45^{\circ} \mathrm{C}$, respectively, after 6 months of storage. Protein digestibility decreased by 5.19 and $9.0 \%$ at 25 and $45^{\circ} \mathrm{C}$, respectively, whereas decrease in starch digestibility was $9.86 \%$ at $25^{\circ} \mathrm{C}$ and $15.1 \%$ at $45^{\circ} \mathrm{C}$ on storage of maize grains for 6 months. However, no significant nutritional changes occurred during storage of maize grains at $10^{\circ} \mathrm{C}[22]$.

Moreover, [23] conducted a study where maize was brought to three moisture contents (m.c.) within the range typically observed in farm and commercial storage, and was inoculated to simulate the amount of storage mold contamination typical of this situation. Certain of the experimental units were packed in 
insulation so that heat could accumulate within the grain masses to simulate hot spots. The wettest grain heated rapidly and became semi-anaerobic. The hot grain then dried rapidly, with the amount of moisture loss influenced by the ratio of water vapor pressures inside and outside the grain. The hot grain cooled and became more aerobic over time. New infections by storage molds, disappearance of viable field molds, development of kernel damage, and changes in atmospheric gases within the grain masses were correlated with the grain moisture or temperature and the rate at which the moisture and temperature changed. The rate of increase in new kernel damage was as high as $3.3 \%$ per week [23]. Both the rate of respiration and the estimated ratio of starch to fat consumed were associated with the mean grain m.c. during the trial, and the estimated ratio of starch to fat consumed was in the range of 2.2/1 - 2.6/1 in the grain containing $16.6-18.2 \%$ m.c. That both fat and starch were consumed calls into question loss estimates based on starch metabolism alone. The fat content of the grain decreased more than $10 \%$ in some experimental units, but increased less than $5 \%$ in others. The protein content generally increased as other grain constituents were consumed [23].

Simultaneously, with the measurement realized inside of the floored warehouse, we monitored external conditions during the storage, i.e. air moisture and temperature, which have a significant impact on storage conditions.

Measured values of atmospheric temperature and extraneous moisture in the area of monitored floored warehouse are represented graphically in Figure 6.

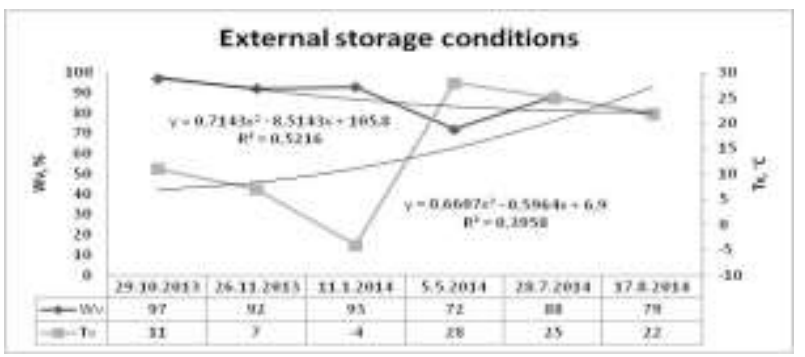

Fig. 6. Progress of air moisture and temperature during the storage in the area of monitored floored warehouse in dependance on storage period $: \mathrm{W}_{\mathrm{v}}$ - air moisture, $\mathrm{T}_{\mathrm{v}}-$ air temperature.

From the measured values we can state, that an average value of air moisture is $86.8 \%$ within the timeframe, with the maximum value of $97 \%$, and minimal value of $72 \%$. We can state, that that an average value of air temperature in the area of warehouse is $14.8^{\circ} \mathrm{C}$, with a maximum value of $28^{\circ} \mathrm{C}$ and minimal value of $-4^{\circ} \mathrm{C}$. Similarly, air moisture correlates with air temperature. A reduction of atmospheric temperature is increasing extraneous moisture, resulting in a direct impact on the course of moisture and temperature of stored maize grain in floored warehouse (Figure 5).

However, [24, 26] conducted a study to assess whether maize can be safely stored in PICS bags without loss of quality, we carried out laboratory studies of maize grain infested with Sitophilus zeamais
(Motshulsky) and stored in PICS triple bags or in woven polypropylene bags. In this study, over an eight month observation period, temperatures in the bags correlated with ambient temperature for all treatments. Relative humidity inside PICS bags remained constant over this period despite the large changes that occurred in the surrounding environment. Relative humidity in the woven bags followed ambient humidity closely. PICS bags containing $\mathrm{S}$. zeamais-infested grain saw a significant decline in oxygen compared to the other treatments. Grain moisture content declined in woven bags, but remained high in PICS bags. Seed germination was not significantly affected over the first six months in all treatments, but declined after eight months of storage when infested grain was held in woven bags [24]. Relative damage was low across treatments and not significantly different between treatments. It was concluded that overall, maize showed no signs of deterioration in PICS bags versus the woven bags and PICS bags were superior to woven bags in terms of specific metrics of grain quality [24].

In addition, [25] concluded that PICS bags are effective at preserving the dryness of maize seed in storage during high relative humidity conditions, which leads to maintenance of seed quality [25].

\section{Conclusions}

Based on experimental measured results and their evaluation can be stated, that extraneous conditions during the storage, i.e. atmospheric temperature and extraneous moisture have a significant impact on the conditions of maize grain storage.

Considering conditions, better results were observed for steel silo storage with a possibility of extraventilation stored layers. An average value of maize grain moisture was $13.6 \%$ and an average value of temperature inside of the silo was $12.3^{\circ} \mathrm{C}$ within a defined timeframe.

An average moisture value of maize grain stored in the floored warehouse was $13.7 \%$, but an average temperature inside the warehouse was $21.9^{\circ} \mathrm{C}$, however extraneous conditions during the storage were unchanged. Average value of extraneous moisture was $86.5 \%$ and an average value of atmospheric temperature was $9.17^{\circ} \mathrm{C}$.

We did not record any occurrence of animal pests in stored maize grain during the storage.

Grain water content differs with the change of air moisture and temperature. Reduction of grain water content is most frequently realized by residual drying (moisture is less than 15\%); the storage stability is provided at the moisture of $12 \%$.

The topic of the cereals storage in relation to machines, technological and economical point of view poorly understood in the Slovak Republic, hence this topic will be the subject of further research by the Department of Machinery and Production Systems, Faculty of Engineering, SUA. 


\section{Acknowledgements}

The research leading to these results has received funding from the European Community under project no 26220220180: Building of Research Centre „AgroBioTech".

\section{References}

1. J. Yang, H. Wang, Y. Gao, J. Li, B. Hu, Influence of hot air and natural drying on extrusion properties of maize. American Society of Agricultural and Biological Engineers Annual International Meeting, 3: 2238-2249, (2011)

2. M. Angelovič, J. Jobbágy, P. Findura, S. Fiantoková, Savremena poljoprivredna tehnika, 41(1): 1-8 (2015)

3. P. Doležal et al. Krmovinářství, 4: 28 - 31 (2014)

4. M. Angelovič, P. Findura, S. Fiantoková, A. Krakowiak, U. Ziemanczyk, K. Rutkowski, Komunální technika. 8: 20-26 (2014)

5. B. P. Marks, R. L. Stroshine, Journal of Stored Products Research, 31(4): 343-354 (1995)

6. J. S. Burris, Postharvest Biology and Technology, 3(2), 155-164 (1993)

7. M. I. El-Abady, Research Journal of Seed Science, 7: 75-86 (2014)

8. A. Talla, Predicting sorption isotherms and net isosteric heats of sorption of maize grains at different temperatures. International Journal of Food Engineering, 10(3): 393-401 (2014)

9. D. Ortiz, T. Rocheford, M. G. Ferruzzi, Journal of Agricultural and Food Chemistry, 64(13), 27272736 (2016)

10. J. Jech, et al., Research of the effects of technical and technological conditions on efficiency of postharvest treatment lines for cereals [In Slovak: Výskum vplyvu technických a technologických podmienok na účinnost' liniek pozberovej úpravy obilnín]. In: Záverečná správa čiastkovej úlohy 01VTP.č. 27-23, KSVS. Nitra: SUA, 140 p (2002)

11. M. Angelovič, S. Fiantoková, M. Angelovič, Scientific papers Animal Science and Biotechnologies, 46(2): 431-436 (2013)

12. I. O. Daniel, K. O. Oyekale, M. O. Ajala, L. O. Sanni, M. A. Okelana, J. A. Adetumbi, A. C. Akintobi, A. Adebisi, Research Journal of Seed Science, 5(1): 32-37 (2012)

13. J. K. Ward, J. D. Davis, Transactions of the ASABE, 56(4): 1503-1509 (2013)

14. J. Skalický et al. 2008. The treatment and storage of cereals in steel silos and floored warehouses Methodology MZe ČR [In Czech: Ošetřování a skladování zrnin ve věžových zásobnících a halových skladech (Metodická př́ručka MZe ČR). Prague: Research institute of agricultural machinery (2008)

15. P. Findura, J. Turan, M. Angelovič, P. Zemánek, M. Prístavka, O. Kuruc, Acta technologica agriculturae, 14: 5-7 (2011)
16. Niemiec M, Sikora J., Szeląg-Sikora A., Kuboń M., Olech E., Marczuk A. Przemysł chemiczny 96(3),685-688 (2017)

17. R. T. Paraginski, B. A. Rockenbach, R. F. Dos Santos, M. C. Elias, M. De Oliveira, Revista Brasileira de Engenharia Agricola e Ambiental, 19(4): 358-363 (2015)

18. J. Mareček, H. Frančáková, The effect of storage in large-capacity warehouses on the qualitz of selected varieties of malting barley [In Slovak: Vplyv vel'kokapacitného skladovania na kvalitu vybraných odrôd sladovníckeho jačmeňa]. In: Safety and conrol of foodstuff (Proccedings of VIII. international conference, Nitra, 30-31 March 2011)[In Slovak: Bezpečnost' a kontrola potravín (Zbornik prác z VIII. medzinárodnej vedeckej konferencie, Nitra 30. - 31. marec 2011). Nitra: SUA, 2011, pp. 250 - 252. ISBN 978-80-5520559-5 (2011)

19. R. T. Paraginski, N. L. Vanier, J. D. J. Berrios, M. de Oliveira, M. C. Elias, Journal of Stored Products Research, 59: 209-214 (2014)

20. M.Volenik, V. Rozman, I. Kalinovic, A. Liska, D. Kiš, B. Šimić, Agriculturae Conspectus Scientificus, 72(3): 215-219 (2007)

21. M. C. Gough, Journal of Agricultural Engineering Research, 31(1): 55-65 (1985)

22. D. C. Lopes, J. H. Martins, A. J. Steidle Neto, A. F. Lacerda Filho, E. C. Melo, P. M. B. Monteiro, Biosystems Engineering, 101(3): 325-330 (2008)

23. Z.U. Rehman, F. Habib, S. I. Zafar, Food Chemistry, 77(2): 197-201 (2002)

24. C. Reed, S. Doyungan, B. Ioerger, A. Getchell, Journal of Stored Products Research, 43(4): 443458 (2007)

25. S. B. Williams, L. L. Murdock, D. Baributsa, Storage of maize in Purdue Improved Crop Storage (PICS) bags. PLoS ONE, 12(1): e0168624 (2017)

26. I. Afzal, M. A. Bakhtavar, M. Ishfaq, M. Sagheer, D. Baributsa, Journal of Stored Products Research, 72: 49-53 (2017) 